\title{
Platelet Count and Mean Platelet Volume in the Prediction of Colorectal Cancer in Patients Presented with Emergency lleus
}

\author{
Trombosit Sayısı ve Ortalama Trombosit Hacminin Acil Ileusu Olan Hastalarda Kolorektal \\ Kanseri Öngörmesi
}

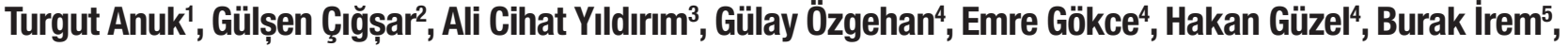
Ahmet Kama ${ }^{6}$, Saygı Gülkan ${ }^{7}$, Göktürk Gürsoy ${ }^{4}$

${ }^{1}$ Department of General Surgery, Kafkas University School of Medicine, Kars, Turkey; ${ }^{2}$ Department of Emergency Medicine, Kafkas University School of Medicine, Kars, Turkey; ${ }^{3}$ Department of General Surgery, Ministry of Health Kars State Hospital, Kars, Turkey; ${ }^{4}$ Department of General Surgery, Dıskkapı Yildrrm Beyazıt Training and Research Hospital, Ankara, Turkey; ${ }^{5}$ Department of General Surgery, Ministry of Health Malkara State Hospital, Tekirdağ, Turkey; ${ }^{6}$ Department of Emergency Medicine, Ministry of Health Kars State, Kars, Turkey; ${ }^{7}$ Social Security Institution, Ankara
\end{abstract}

\begin{abstract}
AIM: We aimed to investigate whether there is a role of platelet number and mean platelet volume in the prediction of colorectal cancer in emergency ileus patients.

METHODS: In this retrospective study, ileus cases undergone urgent laparotomy were split into two groups as: Group 1 (G1) included colorectal cancer patients diagnosed with intra operative findings and Group 2 (G2) included patients without cancer. Platelet count and mean platelet volume values were compared between two groups.

RESULTS: Distribution of female/male patients between groups were homogeneus ( $p$ : 0.724), however mean age of colorectal cancer cases were higher ( $p: 0.008)$. Mean platelet volume values and platelet count were higher in cases with colorectal cancer ( $p$ : 0.040 and p: 0.004 , respectively). Mean platelet volume had 63.3 $\%$ sensitivity and $56.5 \%$ specifity, and platelet count had $63.3 \%$ sensitivity and $62.9 \%$ specifity in prediction of colorectal cancer amongst emergency ileus cases.
\end{abstract}

CONCLUSION: Higher platelet count and mean platelet volume values may predict colorectal cancer in cases with acute abdomen diagnosed with ileus.

Key words: colorectal cancer; ileus; mean platelet volume; platelet

\section{ÖZET}

AMAÇ: Trombosit sayısı ve ortalama trombosit hacminin acil ileus endikasyonu ile ameliyat edilen hastalarda kolorektal kanseri öngörmede rolü olup olmadığını araștırmayı amaçladık.

Uzm. Dr. Gülay Özgehan, Dıskapı Yıldırım Beyazıt Training and Research Hospital, İrfan Baștuğ Cad. Ankara, Türkiye Tel. 03125962313

Email.gulaykemaloglu@gmail.com

Received: 22.11.2014 - Accepted: 21.04.2015
YÖNTEM: Bu retrospektif çalıșmada, ileus tanısıyla acil laparotomi yapılan hastalar iki gruba ayrıld: Grup 1 (G1) intraoperatif bulgulara göre kolorektal kanser tanısı alanlar ve Grup 2 (G2) kanseri olmayan hastalar. Trombosit sayısı ve ortalama trombosit hacmi iki grup arasında karșılaștırıldı.

BULGULAR: Gruplar arası kadın/erkek dağılımı homojendi ( $p$ : 0,724), ancak kolorektal kanser saptanan hastalardaki yaș ortalaması daha yüksek idi (p: 0,008). Kolorektal kanser saptanan hastalardaki ortalama trombosit hacmi ve trombosit sayısı anlamlı düzeyde yüksekti (sırasıyla, p: 0,040 ve p: 0,004). Kolorektal kanseri öngörmede; ortalama trombosit hacmi \%63,3 sensitivite, \%56,5 spesifite ve trombosit sayısı \%63,3 sensitivitesi ve \%62,9 spesifiteye sahipti.

SONUÇ: Akut abdomeni olan ve ileus tanısı konulan olgularda, daha yüksek trombosit sayısı ve ortalama trombosit hacmi kolorektal kanseri öngörebilir.

Anahtar kelimeler: kolorektal kanser; ileus, ortalama trombosit hacmi; platelet

\section{Introduction}

Ileus is complete or partial obstruction of intestinal content's distal transition and develops depending on mechanic or paralytic reasons in intestinal peristalsis. Approximately $80 \%$ of ileus develops in small intestine and its frequency increases in middle aged and elderly patient population ${ }^{1}$.

Etiological factors have a direct dependency on the age of the patient. While congenital abnormalities are most dominant reasons in newborn infants and children, adhesions in adults, and adhesions and malignancy in geriatric population take place on the top ${ }^{2}$. Management 
varies from conventional medical therapy to massive intestine resections.

Thrombocytes (platelets) are blood cells playing the primary role in homeostasis and coagulation. They are small, coreless, ovoid or round cells. Blood concentration is between 150,000 and $400,000 / \mathrm{L}$. Their half life is $8-12$ days.

Thrombocyte volume and increase in its size as well as its number are used in evaluation of inflammatory response in body. In different studies conducted, while it is denoted that platelet volume increases in such cases as acute coronary syndrome, diabetes mellitus, cerebrovascular accidents, hypercholesterolemia, increase in intra abdominal pressure, sepsis and malignancy ${ }^{3-8}$.

In this study, we aimed to investigate whether there is a role of platelet number and mean platelet volume in the prediction of colorectal cancer in emergency ileus patients.

\section{Methods}

In this retrospective study, the records of 105 patients admitted to emergency service between the dates of January 2013 and October 2014 were evaluated. In accordance with Helsinki Declaration criteria, in pursuit of receiving local ethics committee approval we started the study.

The study included the patients with the complaints of abdominal pain, nausea, vomiting and inability to defecate and operated under emergency conditions with the diagnosis of ileus. The diagnosis was dependent on physical examination, laboratory and imaging findings.

Age, gender, platelet number, mean platelet volume (MPV), intra operative findings, surgical procedures and postoperative histo-pathological examinations were analyzed.

Thirteen patients with incomplete and missing records, accessional malignancy, active infection history and blood products transfusion history in the last fifteen days were excluded.

Patients were split into two groups as: Group 1 (G1) included colorectal cancer patients diagnosed with intra operative findings and Group 2 (G2) included patients without cancer. Dependent variables of age, gender, platelet number, mean platelet volume were compared between groups. Reference value for MPV was taken as $7-11 \mathrm{fL}$ and it was taken as
$150-400 \times 10^{9} / \mathrm{L}$ for platelet number. Hematological parameters were studied in ${ }^{\circ}$ LH 780 Analyzer device (Beckman Coulter Inc. Brea, USA).

\section{Statistical Analysis}

The data was analyzed using SPSS for Windows 17 (Chicago, IL, USA) packaged software. Distribution of continuous variables was tested by KolmogorovSmirnov test. Descriptive statistics were denoted as mean \pm standard deviation or median (minimum-maximum) for continuous variables, but categorical variables were pointed out as case number and in the form of percentage (\%). While the significance of the difference between groups in terms of averages was analyzed via student's t-test, it was analyzed via Mann Whitney $\mathrm{U}$ test in terms of median values. Categorical variables were evaluated with the help of Pearson chi-squared test or Fisher's exact chi-square test. The commutual effect of independent variables was detected through cox regression analysis. Roc curve analysis was conducted to calculate the sensitivity, specifity of MPV value and also positive and negative predictive values. For $\mathrm{p}<0.05$, the results were accepted as statistically significant.

\section{Results}

A total of 92 patients' records were suitable for analysis. The median value for the age was 59 (min: 18- max: 81 ) and female/male ratio is 0.56 . All the operations were performed under emergency conditions. Of the 92 patients $30(32.6 \%)$ were diagnosed with colorectal cancer, and 62 were cancer free.

Co-morbid factors including hypertension (HT), diabetes mellitus (DM), coronary artery disease (CAD), chronic obstructive pulmonary disease (COPD) and heart failure (HF), history of a previous laparotomy, and the gender distribution of the patients was summarized in Table 1.

The mean age was significantly higher in G1 in comparison with G2 (65.3 \pm 11.2 and $54.4 \pm 17.3$, p: 0.008$)$. MPV values of $8.64 \pm 0.88 \mathrm{fL}$ in G1 were significantly higher than the MPV values of $8.22 \pm 0.70 \mathrm{fL}$ in G2 (p: $0.04)$. Similarly, platelet number was significantly higher in G1 in comparison with G2 (336400 $102600 /$ $\mathrm{mm}^{3}$ versus $271300 \pm 89200 / \mathrm{mm}^{3}$; p: 0.004).

Co-morbid factors such as DM, COPD and CAD effect MPV levels ${ }^{9,10}$. Thus, we performed cox regression analysis to identify the effects of co-morbid factors. 
Table 1. Demographics of the patients included in the study. The data was present as mean $\pm S D$, median or percentage $(N=92)$.

\begin{tabular}{|c|c|c|}
\hline Age & & $58.0 \pm 16.4$ \\
\hline Gender (Female/Male) & & $33 / 59$ \\
\hline Colorectal cancer ratio & & $30(32.6 \%)$ \\
\hline Co-morbid factors & Non-comorbid factors & $33(35.9 \%)$ \\
\hline & Laparotomy history & $41(44.6 \%)$ \\
\hline & $\mathrm{DM}, \mathrm{HT}, \mathrm{CAD}, \mathrm{COPD}, \mathrm{CHF}$ & $18(19.5 \%)$ \\
\hline Performed operation & Bridectomy & $51(55.4 \%)$ \\
\hline & Left hemicolectomy based on left colon tumor & $12(13.0 \%)$ \\
\hline & Ostomy based on inoperable colorectal cancer & $11(12.0 \%)$ \\
\hline & Right hemicolectomy based on right colon tumor & $5(5.4 \%)$ \\
\hline & Bezoar ileus & $3(3.3 \%)$ \\
\hline & Small intestinal resection based on Crohn's disease & $5(5.4 \%)$ \\
\hline & Small intestinal resection based on strangulated hernia & $2(2.2 \%)$ \\
\hline & LAR/APR based on rectal tumor & $2(2.2 \%)$ \\
\hline & Left hemicolectomy based on volvulus & $1(1.1 \%)$ \\
\hline
\end{tabular}

HT: Hypertension, DM: Diabetes mellitus, CAD: Coronary artery disease, COPD: Chronic obstructive pulmonary disease, CHF: Congestive heart failure, LAR: Low anterior resection, APR: Abdomino perineal resection

The analysis resulted that MPV level and platelet number might predict ileus development in colorectal malignancy in case where effect of age, gender and comorbid factors were neglected ( $\mathrm{p}: 0.004$ and $\mathrm{p}<0.001$, respectively). Roc curve analysis showed a cut-off value of $8.45 \mathrm{fL}$ of MPV had a sensitivity of $63.3 \%$ and a specifity of $56.5 \%$ to predict colorectal cancer in patients with ileus (Figure 1). Similarly, a platelet count cut-off value of $289000 / \mathrm{mm}^{3}$, had a sensitivity of $63.3 \%$ and a specifity of $62.9 \%$ to predict colorectal cancer in patients with ileus (Figure 2).

\section{Discussion}

In our study we identified the MPV and platelet count as useful markers to predict colorectal in cancers in patients undergoing emergency laparotomy with the diagnosis of ileus. However, our study was retrospective and the sample size was relatively small.

Since 1980s, platelet number and platelet volume parameters have been demonstrated together in automatic complete blood count profile without bringing extra costs ${ }^{11}$. The platelet parameters are markers accessed easily, without incremental cost need, stable in femalemale and not effected by menstrual cycle for females ${ }^{11-13}$.
Thus, as markers MPV and platelet count may be studied in primary care units without difficulty.

Ileus occurs in small and large intestines in $80 \%$ and $20 \%$ of the cases, respectively. However, malignancies mostly present with colonic ileus (65\%), while adhesions presenting with small intestinal obstruction $(60 \%)^{14}$. The most frequent surgical procedure ascertained in our study is bridectomy connected with adhesions which has coincided with literature and the gender distribution in ileus is roughly equal ${ }^{15}$.

Blood platelets have a part in many inflammatory events in body. In malignant cases, an increase is seen in platelet numbers with two different mechanisms. The first mechanism is dependent on interleukin-6 (IL-6) by tumor cell and vascular endothelial growth factor stimulus (VEGF) and megacaryocyte activation in bone marrow, whereas the second one is directly dependent on the thrombocytosis of tumor cell ${ }^{16-18}$.

In a study where Karagöz et al. and Pedersen et al. searched platelet number in cases with lung cancer, they stated that platelet number in malignant cases was higher than those in healthy individuals ${ }^{8-19}$. In a research where Jun et al. searched platelet parameters in middle age cancerous cases, MPV, platelet distribution 


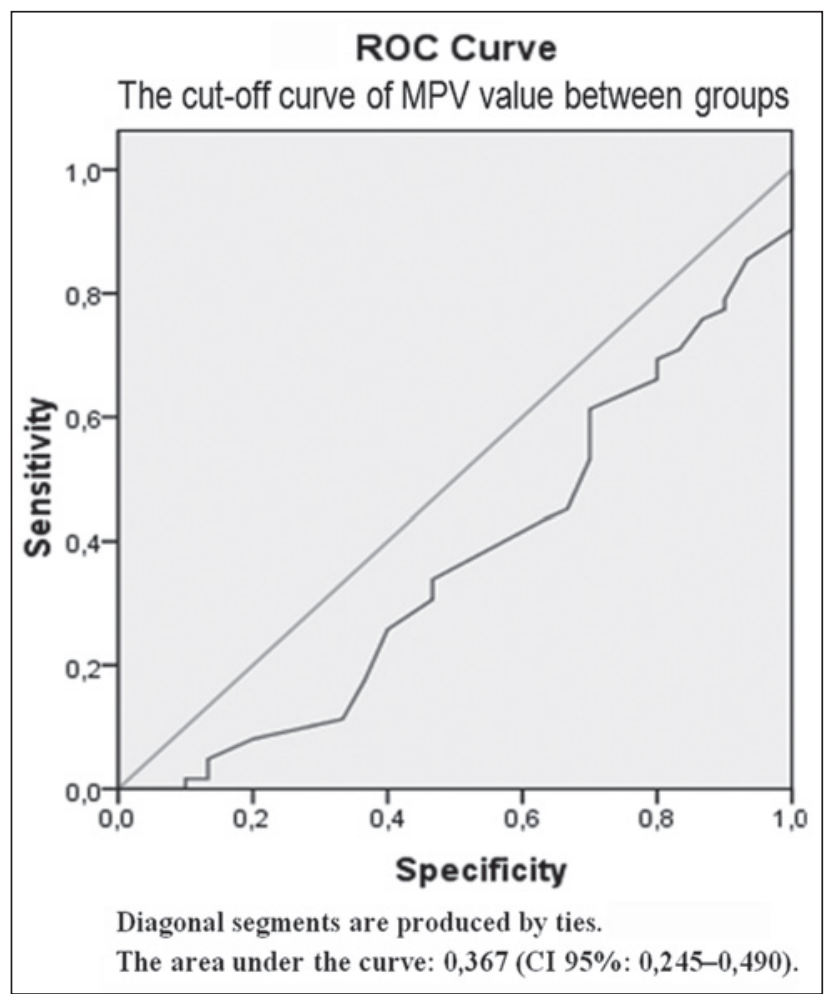

Figure 1. ROC curve of mean platelated volume assesment to predict colorectal cancers in patients presented with emergency ileus.

wideness (PDW) and platelet size were significantly higher in malignant group than healthy group ${ }^{20}$. Ma et al. detected significantly higher levels of platelet counts in high-grade tumors. In addition, platelet number, MPV and PDW was detected higher in malignant group ${ }^{21}$. In harmony with literature, it was identified in our study that both platelet number and MPV level had been significantly higher in the group where colorectal malignancy was detected among the patients operated under emergency conditions with the diagnosis of ileus.

In ileus, shortly the obstruction of intestinal content's distal transition, lots of factors such as hypokalaemia, adhesions, neurological diseases, abdominal hernia, malignancies and intestinal rotation abnormalities may play a role in pathogenesis. Many underlying etiologic factors may cause differences in the sequence of occurrence of the symptoms. Obstruction degree, type and level vary. However, nearly all patients have complaints such as bloating, nausea, vomiting, inability and abdominal pain. In addition, most of the health care centers lack advanced tools. Moreover, it

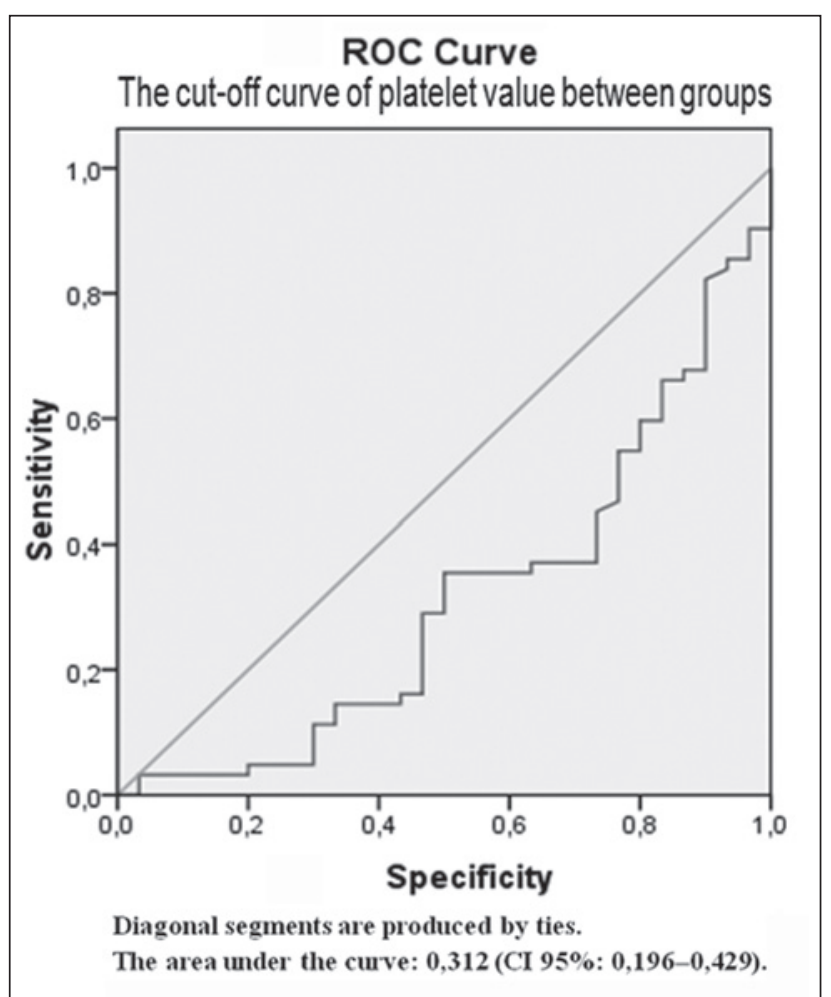

Figure 2. ROC curve of thrombcyte count assesment to predict colo-rectal cancers in patients presented with emergency ileus.

is still difficult to diagnose intestine obstruction under emergency conditions in spite of up-to-date diagnostic and therapeutic modalities. In Turkey, diagnosis-confirmatory urgent endoscopy and tomography service are not available in many centers. Therefore, clinicians seek simple predictive markers to transfer urgent operation indications from pre-diagnosis of ileus-induced acute abdomen to pre-diagnosis of tumor ileus-induced acute abdomen, which is one step further than the former one. Based on this necessity, it has been made out that platelet number and volume analyzed in te study may predict the detection of colon and rectal cancers.

We consider that the increases in platelet number and MPV level measured automatically via routine hemogram test without bringing any extra costs may predict colorectal carcinogenesis at acceptable rates in patients operated under emergency conditions with the diagnosis of ileus-induced acute abdomen. However, the findings of our study should be confirmed with prospective studies including a larger sample size. 


\section{References}

1. Parlak M. İstanbul Üniversitesi Tıp Fakültesi Temel ve Klinik Bilimler 2001:2;1299-319.

2. Değerli Ü, Bozfakığlu F. Cerrahi Gastroenteroloji, Nobel Tıp Kitapevi, 4th edition 1997:283-92.

3. Kristensen SD. The platelet-vessel wall interaction in experimental atherosclerosis and ischaemic heart disease with special reference to thrombopoiesis. Dan Med Bull 1992;39:110-27.

4. Bath PM, Butterworth RJ. Platelet size: measurement, physiology and vascular disease. Blood Coagul Fibrinolysis 1996;7:157-61.

5. Brown AS, Hong Y, de Belder A. et al. Megakaryocyte ploidy and platelet changes in human diabetes and atherosclerosis. Arterioscler Thromb Vasc Biol 1997;17:802-7.

6. Van Der Lelie J, Von Dem Borne AK. Increased mean platelet volume in septicaemia. J Clin Pathol 1983;36:693-6.

7. Celep RB, Kahramanca Ş, Özsoy $M$ et al. Effects of intraabdominal pressure on mean platelet volume during laparoscopic cholecystectomy. Turk J Med Sci 2014;44:360-4.

8. Karagöz B, Alacalığlı A, Bilgi $\mathrm{O}$ et al. Platelet count and platelet distribution width increase in lung cancer patients. Anatol J Clin Investig 2009:3;32-4.

9. Akinsegun A, Akinola OD, Sarah JO et al. Mean platelet volume and platelet counts in type 2 Diabetes: Mellitus on treatment and non-diabetic mellituscontrols in Lagos, Nigeria. Pan Afr Med J 2014:12:1-5.

10. Ayhan S, Ozturk S, Erdem A, et al. Hematological parameters and coronary collateral circulation in patients with stable coronary artery disease. Exp Clin Cardiol 2013;18:12-5.
11. Dow RB. The Clinical and laboratory utility of trombosit volüme parameters. J Med Sci 1994;15:1-15.

12. Bath PM, Butterworth RJ. Trombosit size: measurement, physiology and vascular disease. Blood Coagul Fibrinolysis 1996;7:157-61.

13. Bancroft AJ, Abel W, et al. Mean trombosit volume is a useful parameter: a reproducible routine method using a modified Coulter Thrombocytometer. Trombosits 2000;11:379-87.

14. Mark A. Graber, M D. University of Iowa Family Practice Handbook, Fourth Edition, Chapter 15, 2002:562.

15. Cameron J. L. Current Surgical Therapy. Sixth ed 1998:6;123-32.

16. Ruscetti FW. Hematologic effects of interleukin-1 and interleukin-6. Curr Opin Hematol 1994;1:210-5.

17. Troxler M, Dickinson K, Homer-Vanniasinkam S. Platelet function and antiplatelet therapy. Br J Surg 2007;94:674-82.

18. Gunsilius E, Petzer A, Stockhammer G, et al. Thrombocytes are the major source for soluble vascular endothelial growth factor in peripheral blood. Oncology 2002;58:169-74.

19. Pedersen LM, Milman N. Prognostic significance of thrombocytosis in patients with primary lung cancer. Eur Respir J 1996;9:1826-30.

20. Jun H, Liyan C, Jiesheng L. The changes of platelet parameters in middle-aged patients of cancer. International Journal of Laboratory Medicine 2011:3;337-9.

21. Ma X, Wang Y, Sheng $H$ et al. Prognostic significance of thrombocytosis, platelet parameters and aggregation rates in epithelial ovarian cancer. J. Obstet Gynaecol Res 2014:1;178-83. 